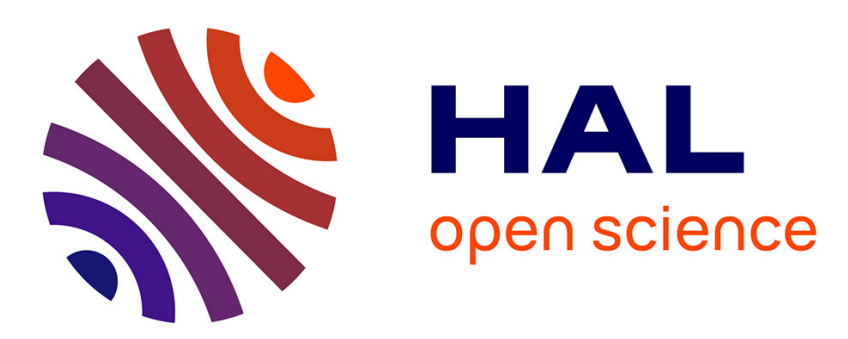

\title{
Nitroxyl Radical Self-Assembled Monolayers on Gold: Versatile Electroactive Centers system in both Aqueous and Organic Media
}

Olivier Alévêque, Fawzia Seladji, Christelle Gautier, Marylène Dias, Tony Breton, Eric Levillain

\section{To cite this version:}

Olivier Alévêque, Fawzia Seladji, Christelle Gautier, Marylène Dias, Tony Breton, et al.. Nitroxyl Radical Self-Assembled Monolayers on Gold: Versatile Electroactive Centers system in both Aqueous and Organic Media. ChemPhysChem, 2009, 10 (14), pp.2401 - 2404. 10.1002/cphc.200900448 . hal01390652

\section{HAL Id: hal-01390652 \\ https://hal.science/hal-01390652}

Submitted on 16 Jul 2020

HAL is a multi-disciplinary open access archive for the deposit and dissemination of scientific research documents, whether they are published or not. The documents may come from teaching and research institutions in France or abroad, or from public or private research centers.
L'archive ouverte pluridisciplinaire HAL, est destinée au dépôt et à la diffusion de documents scientifiques de niveau recherche, publiés ou non, émanant des établissements d'enseignement et de recherche français ou étrangers, des laboratoires publics ou privés. 
Entry for the Table of Contents

Layout 1:

Electrochemistry

O. Alévêque, F. Seladji, C. Gautier, M. Dias
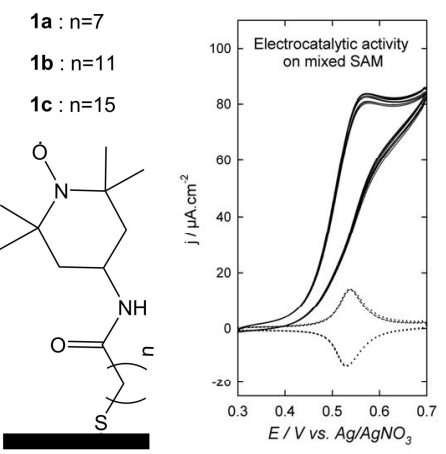

Nitroxyl radical self-assembled monolayers (SAMs) on gold afford a noteworthy electrochemical stability in both aqueous and organic media. The control of the redox center accessibility using mixed SAMs is illustrated by the electrocatalytic activities towards benzyl-alcohol monolayers on gold: versatile electroactive centers system in both aqueous and organic media. oxidation in $\mathrm{CH}_{2} \mathrm{Cl}_{2}$ and $\mathrm{H}_{2} \mathrm{O}$. 


\title{
Nitroxyl radical self-assembled monolayers on gold: versatile electroactive centers in both aqueous and organic media.
}

\author{
O. Alévêque, F. Seladji, C. Gautier, M. Dias, T. Breton* and E. Levillain*
}

Dedicated to Professor E. Laviron

Since the pioneering work by Nuzzo and Allara in 1983, ${ }^{[1]}$ self-assembled monolayers (SAMs) of alkanethiols have gained much attention in the interfacial electrochemistry and other research fields. ${ }^{[2,3]}$ During the last decade,${ }^{[4,5]}$ increasing attention has been dedicated to the design and elaboration of redox-responsive SAMs. Employing redox SAM-modified electrodes for catalysis, recognition and sensing have resulted in some elegant examples that incorporate sophisticated receptors on the electrode surfaces. ${ }^{[5]}$ However, to the best of our knowledge, no redox-responsive SAM was designed to be active and stable in both aqueous (on wide range of $\mathrm{pH}$ ) and organic media.

TEMPO (2,2,6,6-Tetramethylpiperidine-1-oxyl) and its derivatives (under their oxoammonium form) have been extensively studied in the search for organic synthesis as a redox mediator, mostly, for the oxidation of primary alcohols. $^{[6,7,8]}$ The electrochemical oxidation of TEMPO is known to be a stable and reversible one-electron process in both aqueous $[9,10,11]$ and non-aqueous electrolytes. ${ }^{[12,13]}$ Despite the wide electrochemical applications of nitroxyl radical, rare works have been devoted to design and elaborate of redox-responsive TEMPO SAMs. ${ }^{[1,15,16]}$ In 1997, Fuchigami et $a l^{[14]}$ have reported the first preparation of stable self-assembled TEMPO-modified electrodes in acetonitrile: the electrochemical stability was only reached with highly diluted mixed SAMs of nitroxyl radical derivative and hexadecanethiol. In 1999, Kashiwagi et al. ${ }^{[15]}$ have reported electrocatalysis attempts of amines with a mixed SAM of chiral nitroxyl radical derivative and hexadecanethiol: as mentioned by authors, results could be applied to the determination of optical purity of chiral amines. After a ten-years pause, Finklea et. al. ${ }^{[15]}$ have worked on $\mathrm{Au}-\mathrm{S}\left(\mathrm{CH}_{2}\right)_{10} \mathrm{C}(\mathrm{O}) \mathrm{N}(\mathrm{H})$-TEMPO SAM to the first

[*] Dr. O. Alévêque, Dr. C. Gautier, Dr. M. Dias, Dr. T. Breton and Dr. E. Levillain

Laboratoire CIMA - Université d'Angers - CNRS

2 boulevard Lavoisier 49045, Angers cedex (France)

E-mail: tony.breton@univ-angers.fr and eric.levillain@univangers.fr

Dr. F. Seladji

Laboratoire de chimie et d'électrochimie des complexes organométalliques.

Université des Sciences et de la technologie Mohammed Boudiaf BP 1505 - El'M'naouer ORAN (Algérie)

[**] This work was supported by the Centre National de la Recherche Scientifique (CNRS - France), the "Agence Nationale de la Recherche" (ANR - France), and the "Région des Pays de la Loire" (France). We gratefully thank Pr. David Rondeau for MS experiments and helpful discussions.

Supporting information for this article is available on the WWW under http://www.angewandte.org or from the author. estimation of the standard rate constant and the reorganization energies of TEMPO/TEMPO ${ }^{+}$in $1 \mathrm{M} \mathrm{H}_{2} \mathrm{SO}_{4}$.

Herein, we raised the challenge of a design of redoxresponsive TEMPO SAMs to be active, stable and providing electrocatalytic activities in both aqueous and non-aqueous solvents. To reach this goal, we synthesized the three nitroxyl radical derivates $\mathbf{1 a}, \mathbf{1 b}$ and $\mathbf{1 c}$ shown in Scheme 1. The synthesis of 1a, $\mathbf{1 b}$ and $\mathbf{1 c}$ were carried out as outlined in Scheme 1. $\omega$-thioacetyl carboxylic acids with different carbon chains length 2a-c were synthesized from the corresponding $\omega$-bromocarboxylic acids by nucleophilic displacement with potassium thioacetate in DMF. ${ }^{[1]}$ 4aminoTEMPO was coupled to $\omega$-thioacetyl carboxylic acids 2a-c via the active ester method, using dicyclohexylcarbodiimide (DCC) and 1hydroxybenzotriazole (HOBT) in methylene chloride $\left(\mathrm{CH}_{2} \mathrm{Cl}_{2}\right)$, to give the TEMPO derivatives 3a-c in good yields (77 to $84 \%$ ). The thioacetates 3a-c were subsequently deprotected to thiols 1a-c, under basic conditions, using CsOH. $\mathrm{H}_{2} \mathrm{O}$ in a mixture of $\mathrm{THF}$ and $\mathrm{MeOH}$ (yields: 50 to $91 \%)$.

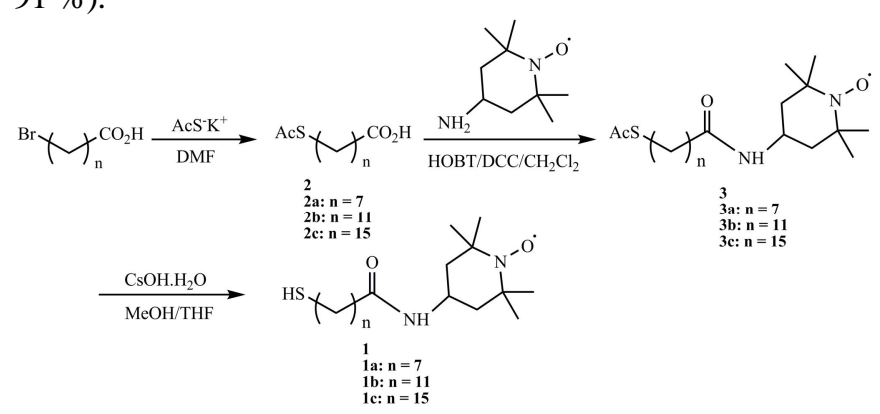

Scheme 1. Synthesis of nitroxyl radical derivatives $1 \mathrm{a}, \mathbf{1 b}$ and $\mathbf{1 c}$.

Cyclic voltammograms $(\mathrm{CVs})^{[18]}$ of $\mathbf{3 a}, \mathbf{3 b}$ or $\mathbf{3 c}$ exhibit a reversible one-electron process in $\mathrm{CH}_{2} \mathrm{Cl}_{2}$ and $\mathrm{CH}_{3} \mathrm{CN}$, close to $0.56 \mathrm{~V}$ and $0.41 \mathrm{~V}$ (vs. $\mathrm{Ag} / \mathrm{AgNO}_{3}$ in $0.1 \mathrm{M}$ $\mathrm{Bu}_{4} \mathrm{NPF}_{6}$ ) respectively.

The kinetics for the formation of SAMs, prepared on $\mathrm{Au}$ substrate ${ }^{[19]}$ from $1 \mathrm{mM}$ solution of $\mathbf{1 a}, \mathbf{1 b}$ or $\mathbf{1 c}$ in $\mathrm{CH}_{2} \mathrm{Cl}_{2}$ or $\mathrm{CH}_{3} \mathrm{CN}$, were followed by using quartz crystal microbalance (QCM) measurements. By employing, the Langmuir adsorption isotherm model, ${ }^{[20]}$ it is possible to establish that deposition kinetics are chain length (n) dependent: $\mathrm{k}_{\mathrm{s}}$ increase with $\mathrm{n}$ and are smaller than $0.1 \mathrm{~s}^{-1}$ (Figure SI-1). ${ }^{[3]}$ A maximum coverage, close to $\sim 4.5 \times 10^{-10} \mathrm{~mol} . \mathrm{cm}^{-2}$ in both solvents, is reached within a few minutes $\left(\tau_{99 \%}<3\right.$ min for 1a).

In non-aqueous solvents (i.e. $\mathrm{DCM}$ or $\mathrm{CH}_{3} \mathrm{CN}$; $\mathrm{Bu}_{4} \mathrm{NPF}_{6} 0.1 \mathrm{M}$ ), the electrochemical properties of SAM prepared from 1a, $\mathbf{1 b}$ or $\mathbf{1 c}$ were very similar to those reported above for $\mathbf{3 a}, \mathbf{3 b}$ or $\mathbf{3 c}$ in solution (vide supra), but 
the shape of voltammetric waves and the linear dependency between peak intensities and scan rates were characteristic of surface-confined redox species (Figure 1). CVs parameters are quasi chain-length (n) independent (Table 1) and surface coverages, deduced by integration of the voltammetric signal, are in agreement with QCM experiments in both solvents. Interestingly, shapes of voltammetric waves are solvent and supporting electrolyte dependent: sharp (FWHM $\sim 36 \mathrm{mV}$ ) in $0.1 \mathrm{M} \mathrm{Bu} \mathrm{NPF}_{6} / \mathrm{CH}_{2} \mathrm{Cl}_{2}$ and broad (FWHM $\sim 117 \mathrm{mV}$ ) in $0.1 \mathrm{M} \mathrm{Bu}_{4} \mathrm{NPF}_{6} / \mathrm{CH}_{3} \mathrm{CN}$ (Figure 1 and Table 1).

Table 1. CV parameters of SAMs prepared from $1 b$.

\begin{tabular}{|c|c|c|c|c|}
\hline Medium & at $0.1 \mathrm{~V} . \mathrm{s}^{-1}$ & $\mathrm{CH}_{2} \mathrm{Cl}_{2}$ & $\mathrm{MeCN}$ & $\mathrm{H}_{2} \mathrm{O}$ \\
\hline \multirow{3}{*}{$\begin{array}{c}0.1 \mathrm{M} \\
\mathrm{Bu}_{4} \mathrm{NPF}_{6}\end{array}$} & $\Gamma\left(\mathrm{mol}^{\mathrm{cm}} \mathrm{cm}^{-2}\right)$ & $4.7 \times 10^{-10}$ & $4.5 \times 10^{-10}$ & \multirow[t]{3}{*}{ 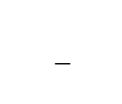 } \\
\hline & FWHM (mV) & 36 & 117 & \\
\hline & $\mathrm{E}_{\mathrm{p}}(\mathrm{V})$ & $0.52^{\mathrm{a}}$ & $0.49^{a}$ & \\
\hline \multirow{3}{*}{$\begin{array}{c}0.1 \mathrm{M} \\
\mathrm{NaClO}_{4}\end{array}$} & $\Gamma\left(\mathrm{mol}^{\mathrm{c}} \mathrm{cm}^{-2}\right)$ & \multirow{3}{*}{-} & $4.6 \times 10^{-10}$ & $5.0 \times 10^{-10}$ \\
\hline & FWHM (mV) & & 87 & 96 \\
\hline & $E_{p}(V)$ & & $0.43^{\mathrm{a}}$ & $0.71^{b}$ \\
\hline
\end{tabular}

[a] vs. $\mathrm{Ag} / \mathrm{AgNO}_{3}(0.01 \mathrm{M})$, [b] vs. $\mathrm{Ag} / \mathrm{AgCl} / \mathrm{KCl}_{\text {sat }}$

These reproducible opposite values of full width at half maximum (FWHM) deviate from the expected value $(\sim 89 / \mathrm{n}$ $\mathrm{mV}$ at $293 \mathrm{~K}$ ) of an "ideal system", based on a Langmuir isotherm (i.e. all adsorption sites are equivalents and there are no interactions between immobilized electroactive centers). The interfacial electron transfer process and the interaction between the immobilized functional moieties have been widely studied to clarify the "non ideality" of experimental data $^{[21,22,23,24,25,26,27,28,29,30]}$ but it still remains an open-ended question.

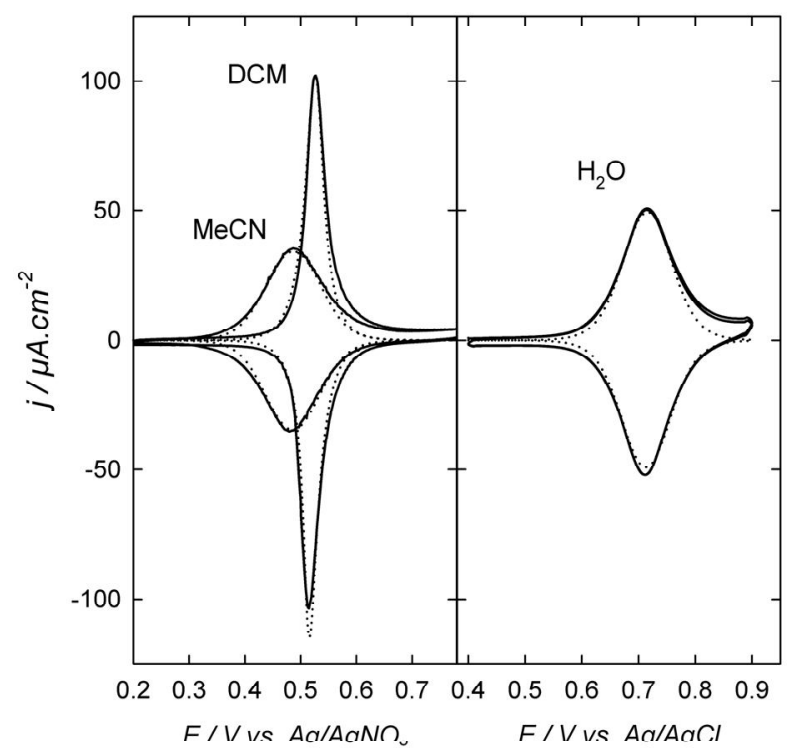

Figure 1. (Solid line): (left): $C V$ s of $S A M$ prepared from $1 \mathrm{~b}$ in $0.1 \mathrm{M}$ $\mathrm{Bu}_{4} \mathrm{NPF}_{6} / \mathrm{CH}_{2} \mathrm{Cl}_{2}$ and in $\mathrm{Bu}_{4} \mathrm{NPF}_{6} / \mathrm{CH}_{3} \mathrm{CN}$; (right): $\mathrm{CVs}$ of SAM prepared from $1 \mathrm{~b}$ in $\mathrm{HClO}_{4} / \mathrm{NaClO}_{4} / \mathrm{H}_{2} \mathrm{O}$; It is noteworthy that $\mathrm{CVs}$ are superimposable upon one another from $\mathrm{pH}=2$ to $\mathrm{pH}=6.6$. (Dashed line): CVs calculated from theoretical models based on a Frumkin type isotherm) ${ }^{[31]}$ All CVs were performed at 0.1 V.s. ${ }^{-1}$.

However, from a Frumkin type isotherm (i.e. all adsorption sites are equivalents and there are interactions between immobilized electroactive centers), Laviron ${ }^{31}$ developed in the seventies a lateral interaction model to account for the sharpness or broadening and shifts of apparent formal potentials of experimental CVs. Based on diagnostic criteria reviewed in reference $31 \mathrm{e}$, strong attractive interactions between immobilized oxidized centers lead to a sharp shape (i.e. in $\mathrm{CH}_{2} \mathrm{Cl}_{2}$ ) and, medium or weak repulsive interactions to a broad shape (i.e. in $\mathrm{CH}_{3} \mathrm{CN}$ ) (Figure 1 and see below Figure 2). Taken in concert, these results suggest that the local ionic environment (coulombic repulsion and solvatation) of charged redox centers plays a significant role in the electrochemical behaviour of the electroactive SAMs.

In aqueous media, a drastic preparation ${ }^{[32]}$ of SAMs is required to reach a stable and reproducible redox activity (Figure SI-2). As in solution, ${ }^{[12,13]}$ apparent redox potentials $\left(\mathrm{E}_{\text {app (at } \mathrm{pH}=7)} \sim 0.71 \mathrm{~V} v s . \mathrm{Ag} / \mathrm{AgCl} / \mathrm{KCl}_{\text {sat }}\right)$ and shape of SAMs prepared from $\mathbf{1 a}, \mathbf{1 b}$ and $\mathbf{1 c}$ are not $\mathrm{pH}$ dependent (Figure 1). Between $\mathrm{pH}=0$ and $\mathrm{pH}=10.5$, voltammetric waves (Figure SI3) are quasi chain-length (n) independent and close to an "ideal system" (i.e. based on a Langmuir isotherm). Surface coverages, deduced by integration of the voltammetric signal, are comparable to the ones assessed in non aqueous solvents (Tableau 1). Beyond $\mathrm{pH}=10.5$, the electrochemical behaviour of SAMs is unstable due to the proximity of the water oxidation.

Because the structure of monolayer limits the accessibility of interfacial reactive sites ${ }^{[3]}$ the control of the structure-electroactivity relationship is decisive for enhancing interfacial reactions. An approach to improve the problems arising from intermolecular interactions is to dilute the electroactive species in the monolayer by mixing alkanethiols. ${ }^{33}$ Indeed, electrochemical behaviours of mixed SAMs, prepared from 1a, 1b or 1c:alkanethiol mixtures, ${ }^{[34]}$ fit with the interaction model developed by Laviron: the full width at half maximum and the apparent redox potential are linearly dependent on the surface coverage (Figure SI-4), and the simulations are in qualitative (i.e. shape) and quantitative (i.e. intensities) agreement with CVs of mixed SAMs (Figure 2 ). The excellent and rare $^{[35]}$ agreement observed between theory and experiments provides evidence of a random distribution of electroactive centers on gold.

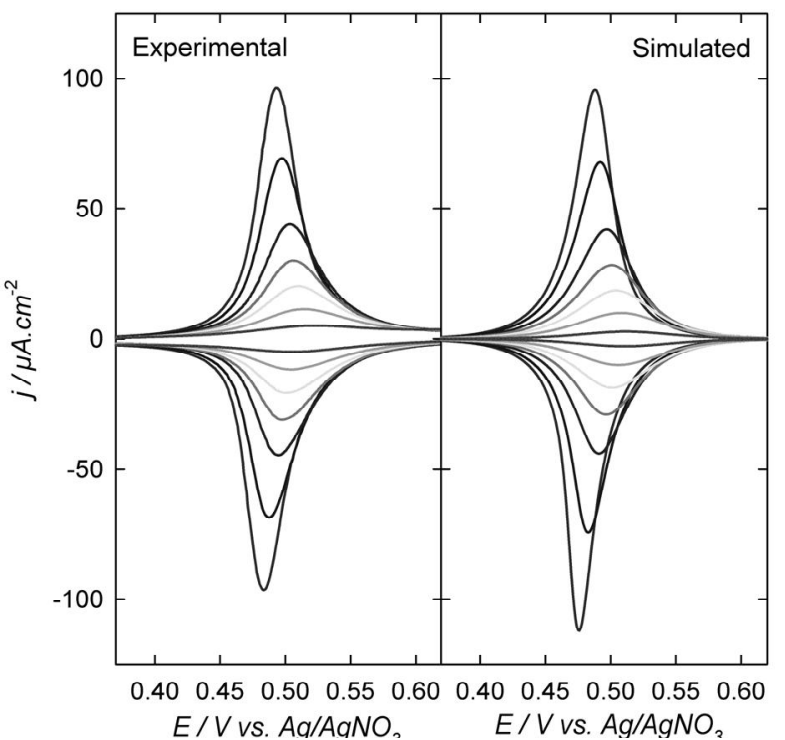

Figure 2. (Left): CVs of SAM prepared from different 1c:decanethiol ratios, leading to $4.6,3.8,2.9,2.1,1.5$ and $0.910^{-10} \mathrm{~mol}^{-\mathrm{cm}^{-2}}$; (Right): CVs calculated from theoretical models based on a Frumkin type isotherm. In addition to the usual electrochemical parameters, calculations were performed with $r_{O}=1.0$ (corresponding to a strong interaction between oxidized centers) and only one variable changes at a time, the surface coverage $(\theta=1.00,0.74,0.62,0.52$ and 0.38$){ }^{[31]}$ All CVs were performed in $0.1 \mathrm{M} \mathrm{Bu}_{4} \mathrm{NPF}_{6} / \mathrm{CH}_{2} \mathrm{Cl}_{2}$ at $0.1 \mathrm{~V} . \mathrm{s}^{-1}$. 
This outlook is established by electrocatalytic activities of SAMs towards benzyl-alcohol oxidation in $\mathrm{CH}_{2} \mathrm{Cl}_{2}$ and in $\mathrm{H}_{2} \mathrm{O}(\mathrm{pH}=10)$. First, SAMs prepared from $\mathbf{1 a}, \mathbf{1 b}$ or $\mathbf{1 c}$ are stable under electrocatalytic conditions because catalytic currents are persistent under repetitive potential scans in aqueous and non aqueous media (Figure 3 and Figure SI-5). Second, mixed SAMs (up to a limiting $\mathbf{1 a}, \mathbf{1 b}$ or 1c:alkanethiol ratio) increase absolute catalytic current in spite of few immobilized electroactive centers (e.g. despite five-fold lower electroative sites, the catalytic current is $50 \%$ higher on mixed SAMs compared to unmixed ones) and improved the stability of electrocatalytic process (Figure 3 ). These results also provide support for the claim ${ }^{[36]}$ that electroactive centers are random distributed on gold. As expected, [ 37 ] oxidations of benzyl-alcohol led to benzaldehyde.

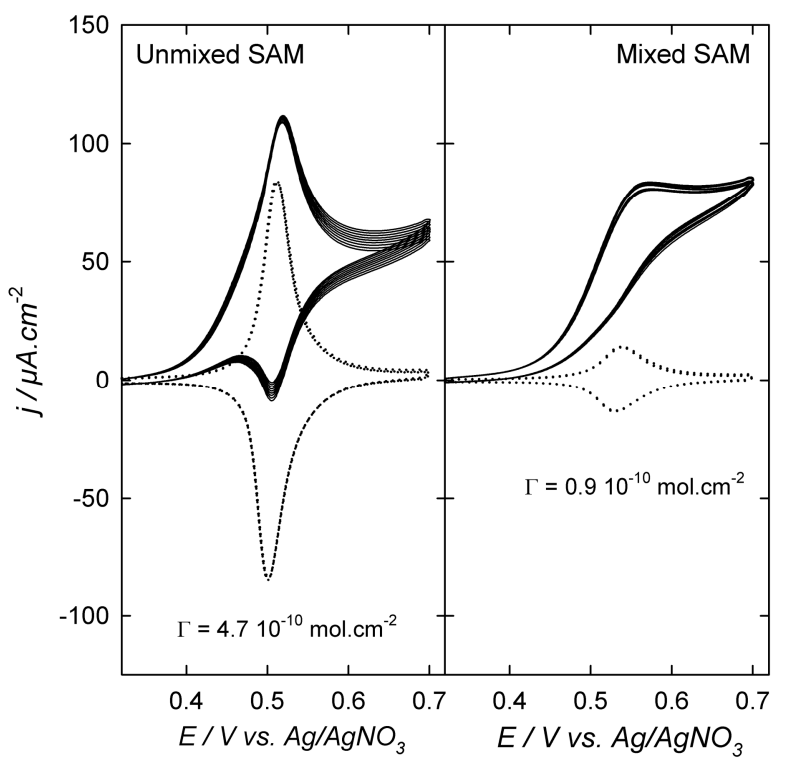

Figure 3. (Dashed line): CVs of SAMs prepared from 1c (left) and from 1c:dodecanethiol (right) in absence of benzyl-alcohol; (Solid line): CVs of SAMs prepared from 1c (left) and from 1c:dodecanethiol (right) in presence of $10 \mathrm{mM}$ benzyl-alcohol. On unmixed SAM in presence of benzyl-alcohol, the persistence of a reversible oxidation wave shows that many redox centers are not active. All CVs were performed with $80 \mathrm{mM}$ of 2,6-lutidine in $0.1 \mathrm{M} \mathrm{Bu}_{4} \mathrm{NPF}_{6} / \mathrm{CH}_{2} \mathrm{Cl}_{2}$ at $0.1 \mathrm{~V} . \mathrm{s}^{-1}$ under 20 repetitive cycles.

In summary, nitroxyl radical SAMs present a noteworthy electrochemical stability in both aqueous (from $\mathrm{pH}=0$ to $\mathrm{pH}=10.5$ ) and organic media. The control of the surface coverage associated with the catalytic properties of oxoammonium cation provide a clear and convincing illustration of potentialities of nitroxyl radical SAMs. Further work is aimed at developing mixed SAMs designed to a redox-responsive material.

Received: ((will be filled in by the editorial staff)) Published online on ((will be filled in by the editorial staff))

Keywords: tempo $•$ self assembled monolayers $\cdot$ cyclic voltammetry $•$ quartz crystal microbalance $\cdot$ electrocatalysis

[1] R.G. Nuzzo, D.L. Allara, J. Am. Chem. Soc.,1983, 105, 4481-4483.

[2] A. Ulman, An Introduction to Ultrathin Organic Films From Langmuir-Blodgett to Self-Assembly; Academic Press: Boston, MA, 1991.

[3] J. C. Love, L. A. Estroff, J. K. Kriebel, R. G. Nuzzo, G. M. Whitesides, Chem. Rev. 2005, 105, 1103-1169.
[4] S. Flink, F. C. J. M. Van Veggel, D. N. Reinhoudt, Adv. Mater. 2000 12, 1315-1328.

[5] S. Zhang, C. M. Cardona, L. Echegoyen, Chem. Commun. 2006, 4461-4473.

[6] V.A. Golubev, E.G. Rozantsev, M.B. Neiman, Bull. Acad. Sci. USSR, 1965, 1927-1936.

[7] A.E.J. De Nooy, A.C. Bessemer, H. Van Bekkum, Synthesis 1996, 10 1153-1174

[8] T. Vogler, A. Studer, Synthesis 2008, 13, 1979-1993.

[9] G. Thomas, J. G. Mohanty, Indian J. Chem. 1982, 21A, 451-455.

[10] J. R. Fish, S. G. Swarts, M. D. Sevilla, T. Malinski, J. Phys. Chem. 1988, 92, 3745-3751.

[11] Y. Kato, Y. Shimizu, L. Yijing, K. Unoura, H. Utsumi, T. Ogata, Electrochim. Acta 1995, 40, 2799-2802.

[12] P. Krzyczmonik, H. Scholl, J. Electroanal. Chem. 1992, 335, 233 251.

[13] K. Nakahara, S. Iwasa, J. Iriyama, Y. Morioka, M. Suguro, M. Satoh, E. J. Cairns, Electrochimica Acta 2006, 52, 921-927.

[14] T. Fuchigami, T. Shintani, A. Konno, S. Higashiya, Denki Kagaku 1997, 65, 506-507.

[15] Y. Kashiwagi, K. Uchiyama, F. Kurashima., J.I. Anzai, J.-I.,T. Osa, Analytical Sciences, 1999, 15, 907-909.

[16] H. O. Finklea, N. Madhiri, J. Electroanal. Chem. 2008, 621, 129-133.

[17] S. Svedhem, C.-A. Hollander, J. Shi, P. Konradsson, B. Liedberg, S. C. T. Svensson, J. Org. Chem. 2001, 66, 4494-4503

[18] Electrochemical experiments were carried out with a Biologic SP-150 potentiostat in a glove box containing dry, oxygen-free $(<1 \mathrm{ppm})$ argon, at $293 \mathrm{~K}$. Cyclic voltammetry (CV) was performed in a threeelectrode cell equipped with a platinum-plate counter electrode. Reference electrodes were $\mathrm{Ag} / \mathrm{AgNO}_{3} \quad\left(0.01 \quad \mathrm{M} \quad \mathrm{CH}_{3} \mathrm{CN}\right)$ or $\mathrm{Ag} / \mathrm{AgCl} / \mathrm{KCl}_{\text {sat }}$. CVs were recorded in dry HPLC-grade methylene chloride, HPLC-grade acetonitrile or $\mathrm{H}_{2} \mathrm{O}$. Supporting electrolytes were tetrabutylammonium hexafluorophosphate $\left(\mathrm{Bu}_{4} \mathrm{NPF}_{6}\right)$ or sodium perchlorate $\left(\mathrm{NaClO}_{4}\right)$. Based on repetitive measurements, absolute errors on potentials were found to be approximately $\sim 5 \mathrm{mV}$.

[19] The substrates were prepared by deposition of ca. $5 \mathrm{~nm}$ of chrome followed by ca. $50 \mathrm{~nm}$ of gold onto a glass substrate using physical vapor deposition techniques and were made immediately before use. See: a) L. Sanguinet, O. Alévêque, P. Blanchard, M. Dias, E. Levillain, D. Rondeau. J. Mass Spectro. 2006, 41, 830-833; b) M. Bounichou, L. Sanguinet, K. Elouarzaki, O. Alévêque, M. Dias, E. Levillain, D. Rondeau. J. Mass Spectro. 2008, 43, 1618-1626.

[20] D. S. Karpovich, G. J. Blanchard, Langmuir, 1994, 10, 3315 3322.

[21] A. Ulman, Chem. Rev. 1996, 96, 1533-1554.

[22] H.O. Finklea, in: A.J. Bard, I. Rubinstein (Eds.), Electroanalytical Chemistry, Vol. 19, Marcel Dekker, New York, 1996, pp. 129-133.

[23] a) C.E.D. Chidsey, Science 1991, 251, 919-922; b) C.E.D. Chidsey, C.R. Bertozzi, T.M. Putvinski, A.M. Mujsce, J. Am. Chem. Soc. 1990, 112, 4301-4306. J.P. Collman, N.K. Devaraj, C.E.D. Chidsey, Langmuir 2004, 20, 1051-1053.

[24] a) K. Uosaki, Y. Sato, H. Kita, Langmuir 1991, 7, 1510-1514; b) K Uosaki, Y. Sato, H. Kita, Electrochim. Acta 1991, 36, 1799-1801.

[25] a) G.K. Rowe, S.E. Creager, Langmuir 1991, 7, 2307-2312; b) S.E. Creager, G.K. Rowe, Anal. Chim. Acta 1991, 246, 233-239; c) G.K. Rowe, S.E. Creager, J. Phys. Chem. 1994, 98, 5500-5507; d) S.E. Creager, G.K. Rowe, Langmuir 1994, 10, 1186-1192; e) S.E. Creager, G.K. Rowe, J. Electroanal. Chem. 1997, 420, 291-299; f) J.J. Sumner, S.E. Creager, J. Phys. Chem. B 2001, 105, 8739-8745.

[26] J.A.M. Sondag-Huethorst, L.G.J. Fokkink, Langmuir 1994, 10, 43804387.

[27] N.L. Abbott, G.M. Whitesides, Langmuir 1994, 10, 1493-1497.

[28] D.M. Collard, M.A. Fox, Langmuir 1991, 7, 1192-1197.

[29] G. Valincius, G. Niaura, B. Kazakeviciené , Z. Talaikyté, M. Kazemékaité ,E. Butkus, V. Razumas, Langmuir 2004, 20, 6631-6638.

[30] Y. Guo Yan Guo, J. Zhao, J. Zhu, Thin Solid Films, 2008, 516, 30513057.

[31] a) E. Laviron, Electroanalytical Chemistry and Interfacial Electrochemistry, 1974, 52, 395-402; b) E. Laviron, J. Electroanal. Chem., 1979, 100, 263-270; c) E. Laviron, L. Roullier, J. Electroanal. Chem., 1980, 115, 65-74; d) A. P. Brown, F. C. Anson, Anal. Chem. 1977, 49, 1589-1595; e) M. J. Honeychurch, G. A. Rechnitz, Electroanalysis 1998, 10, 285-293. 
[32] To reach a stable and reproducible redox activity in aqueous media, SAMs, elaborated from $\mathrm{CH}_{2} \mathrm{Cl}_{2}$, must be immerged in pure $\mathrm{CH}_{3} \mathrm{CN}$ and then in pure $\mathrm{H}_{2} \mathrm{O}$

[33] a) C.E.D. Chidsey, C.R. Bertozzi, T.M. Putvinski, A.M. Mujsce, J. Am.Chem. Soc. 1990, 112, 4301-4306. b) C.E.D. Chidsey, Science 1991, 251, 919-922.

[34] Mixed SAMs were prepared from a mixture TEMPO derivative/Alkanethiol solution. This procedure led to stable and reproducible SAMs.

[35] Rare because, as mentioned by G. M. Withesides (Ref. 3), "There are not enough experimental data to establish detailed structure-reactivity relationships for interfacial reactions on SAMs, especially on mixed SAMs".

[36] To the best of our knowledge, SEM or AFM microscopies are not suitable to confirm this conclusion because subnanometer spatial resolution is required to characterize the organization of mixed SAMs.

[37] Y Hahn, S. Ky. Song, Analytical Sciences, 1997, 13, 329-332. 
Nitroxyl radical self-assembled monolayers on gold: versatile electroactive centers in both aqueous and organic media.

O. Alévêque, F. Seladji, C. Gautier, M. Dias, T. Breton* and E. Levillain*

\section{Supporting Information}

\section{Contents}

EXPERIMENTAL SECTION-

CHARACTERIZATION BY ELECTROCHEMISTRYS6

Figure SI-1 - QCM experiments S6

Figure SI-2 - Electrochemical test of stability $v s$. solvent S6

Figure SI-3 $-\mathrm{CVs}$ at $\mathrm{pH}=2$ vs. scan rate S7

Figure SI-4 - FWHM and Eapp vs. surface coverage S7

Figure SI-5 - Electrocatalytic activity in $\mathrm{H}_{2} \mathrm{O}$ S8

REFERENCESS9 


\section{EXPERIMENTAL SECTION}

Materials. All reagents were purchased from commercial suppliers (Sigma-Aldrich or Acros Organics) and were used without further purification. $\omega$-Thioacetyl carboxylic acids 2a-c were prepared according to literature procedures. ${ }^{[\mathrm{S} 1]}$ Alkanethiols were used as received.

General Methods. All reactions were carried out under an inert $\mathrm{N}_{2}$ or Ar atmosphere. THF was distilled from sodium-benzophenone immediately prior to use. $\mathrm{MeOH}$ was distilled from $\mathrm{Mg}$ and $\mathrm{I}_{2}$ immediately prior to use. Analytical thin layer chromatography (TLC) was performed on Merck DC-Alufolien Kiselgel $60 \mathrm{~F}_{254} 0.2 \mathrm{~mm}$ thickness precoated TLC plates, which were inspected by UV-light prior to development with iodine vapor. Column chromatography was performed using Acros Organics Kiselgel 60 (0.040-0.060 mm, 230-240 mesh ASTM). ${ }^{1} \mathrm{H}$ NMR spectra were recorded at room temperature on a Bruker Advance DRX $500 \mathrm{MHz}$ and ${ }^{13} \mathrm{C} \mathrm{NMR}$ spectra were recorded at $125.75 \mathrm{MHz}$ on a Bruker Advance DRX. Chemical shifts are quoted on the $\delta$ scale and coupling constants $(J)$ are expressed in Hertz (Hz). Samples for ${ }^{1} \mathrm{H}$ NMR spectroscopic studies were prepared using solvents purchased from C.E Saclay Euriso-Top. All spectra were referenced using the residual solvent peak. Exact mass measurements were performed using a JMS-700 (JEOL Ltd, Akishima, Tokyo, Japan) double focusing reversed geometry mass spectrometer. FAB was used as ionisation method in positive ion mode with mNBA as matrix. The sample was introduced into the ion source of the mass spectrometer and irradiated with a xenon gun at $5 \mathrm{keV}$ energy and an emission current of $10.6 \mathrm{~mA}$. The source pressure was kept at $2 \times 10^{-5}$ Torr at room source temperature. A 7-kV acceleration voltage was applied and nominal resolution was 10000 (10\% valley definition). The elemental composition of ions was checked by high resolution measurements using an electric-field scan with a mixture of PEGs as internal standard with nominal molecular weights centered around 600 .

\section{Compound $3 a$}

To a stirred solution of 8-(acetylthio)octanoic acid $\mathbf{2 a}(230 \mathrm{mg}, 1.06 \mathrm{mmol})$ in $\mathrm{CH}_{2} \mathrm{Cl}_{2}(20 \mathrm{~mL})$ at $0^{\circ} \mathrm{C}$ were added 4-aminoTEMPO $(270 \mathrm{mg}, 1.58 \mathrm{mmol})$ in $\mathrm{CH}_{2} \mathrm{Cl}_{2}(5 \mathrm{~mL}), 1$-hydroxybenzotriazole (HOBT) (210 mg, $1.58 \mathrm{mmol})$ and finally dicyclohexylcarbodiimide (330 mg, $1.58 \mathrm{mmol})$. The reaction mixture was allowed to attain room temperature and stirred under $\mathrm{N}_{2}$ for $24 \mathrm{~h}$. The precipitate of dicyclohexylurea was eliminated by filtration. The solvent was evaporated under reduced pressure and the resulting residue was purified by column chromatography (silica gel, 
eluent $\mathrm{CH}_{2} \mathrm{Cl}_{2} / \mathrm{MeOH}$ 96:4) giving 3a as an orange oil (300 mg, $77 \%$ ); ${ }^{1} \mathrm{H}$ NMR (500 MHz, $\left.\mathrm{CDCl}_{3}\right): \delta 1.08-1.45(2 \mathrm{~m}, 4 \mathrm{H}+12 \mathrm{H}), 1.45-1.75(\mathrm{~m}, 8 \mathrm{H}), 1.94(\mathrm{~m}, 2 \mathrm{H}), 2,16(\mathrm{bs}, 2 \mathrm{H}), 2.34(\mathrm{~s}$, $\left.\mathrm{CH}_{3} \mathrm{CO}\right), 2.87\left(\mathrm{t}, \mathrm{CH}_{2} \mathrm{~S}, J=6.8 \mathrm{~Hz}\right), 3.50(\mathrm{bs}, 1 \mathrm{H}) ;{ }^{13} \mathrm{C} \mathrm{NMR}\left(125.75 \mathrm{MHz}, \mathrm{CDCl}_{3}\right): \delta 24.8,25.4$, 25.6, 25.8, 25.9, 28.7, 29.0, 29.3, 29.6, 31.2, 34.5, 35.0, 40.3, 49.2, 172.6, 196.3. FAB-MS: calcd for $\mathrm{C}_{19} \mathrm{H}_{35} \mathrm{~N}_{2} \mathrm{O}_{3} \mathrm{~S}^{\bullet+}$, 371.2368; found: 371.2357.

\section{Compound 1a}

A solution of $\mathbf{3 a}(150 \mathrm{mg}, 0.40 \mathrm{mmol})$ in anhydrous THF $(30 \mathrm{~mL})$ was deoxygenated with $\mathrm{N}_{2}$ for 1 h before a solution of $\mathrm{CsOH} \cdot \mathrm{H}_{2} \mathrm{O}$ (203 mg, $1.21 \mathrm{mmol}, 3$ eq.) in anhydrous $\mathrm{MeOH}(5 \mathrm{~mL})$, which was deoxygenated for $1 \mathrm{~h}$ with $\mathrm{N}_{2}$, was added dropwise via a syringe. The reaction mixture was stirred $4 \mathrm{~h} 30$, whereafter the solvent was evaporated in vacuo and the resulting orange residue was dissolved in $\mathrm{CH}_{2} \mathrm{Cl}_{2}(50 \mathrm{~mL})$, washed with $\mathrm{H}_{2} \mathrm{O}(3 \times 30 \mathrm{~mL})$ and dried $\left(\mathrm{MgSO}_{4}\right)$. Evaporation of the solvent gave an orange oil identified to $1 \mathbf{a}(120 \mathrm{mg}, 91 \%) ;{ }^{1} \mathrm{H} \mathrm{NMR}\left(500 \mathrm{MHz}, \mathrm{CDCl}_{3}\right): \delta 1.05$ 1.55 (m, 17H), 1.60-1.80 (m, 8H), 1.98 (bs, 2H), 2.22 (bs, 2H, $\left.\mathrm{CH}_{2} \mathrm{CO}\right), 2.72$ (bs, 2H, $\mathrm{CH}_{2} \mathrm{~S}$ ), 3.56

(bs, $1 \mathrm{H}) ;{ }^{13} \mathrm{C}$ NMR $\left(125.75 \mathrm{MHz}, \mathrm{CDCl}_{3}\right): \delta 21.5,21.9,22,1,22.2,24.6,25.4,25.6,25.9,30.6$, 35.4, 36.7, 45.3, 168.7; FAB-MS: calcd for $\mathrm{C}_{17} \mathrm{H}_{33} \mathrm{~N}_{2} \mathrm{O}_{2} \mathrm{~S}^{\bullet+}$, 329.2263; found: 329.2275.

\section{Compound $3 b$}

To a stirred solution of 12-(acetylthio)dodecanoic acid $\mathbf{2 b}(230 \mathrm{mg}, 0.84 \mathrm{mmol})$ in $\mathrm{CH}_{2} \mathrm{Cl}_{2}(20 \mathrm{~mL})$ at $0^{\circ} \mathrm{C}$ were added 4-aminoTEMPO $(220 \mathrm{mg}, 1.58 \mathrm{mmol})$ in $\mathrm{CH}_{2} \mathrm{Cl}_{2}$ (5 mL), 1hydroxybenzotriazole (HOBT) (170 mg, $1.26 \mathrm{mmol}$ ) and finally dicyclohexylcarbodiimide (260 $\mathrm{mg}, 1.26 \mathrm{mmol}$ ). The reaction mixture was allowed to attain room temperature and stirred under $\mathrm{N}_{2}$ for $24 \mathrm{~h}$. The precipitate of dicyclohexylurea was eliminated by filtration. The solvent was evaporated under reduced pressure and the resulting residue was purified by column chromatography (silica gel, eluent $\mathrm{CH}_{2} \mathrm{Cl}_{2} / \mathrm{MeOH}$ 96:4) giving 3b as an orange oil (300 mg, $84 \%$ ); ${ }^{1} \mathrm{H}$ NMR (500 MHz, CDCl $)$ : $\delta$ 1.05-1.50 (m, 24H), 1.55-1.80 (m, 8H), $1.96(\mathrm{~m}, 2 \mathrm{H}), 2,19(\mathrm{bs}, 2 \mathrm{H})$, 2.36 (s, $\left.\mathrm{CH}_{3} \mathrm{CO}\right), 2.89$ (t, $\left.\mathrm{CH}_{2} \mathrm{~S}, J=7 \mathrm{~Hz}\right), 3.55$ (bs, $\left.1 \mathrm{H}\right) ;{ }^{13} \mathrm{C} \mathrm{NMR}\left(125.75 \mathrm{MHz}, \mathrm{CDCl}_{3}\right): \delta 23.1$, 26.0, 26.3, 26.4, 26.5, 26.6, 26.7, 26.8, 28.1, 37.3, 51.9, 169.8, 193.4. FAB-MS: calcd for $\mathrm{C}_{23} \mathrm{H}_{43} \mathrm{~N}_{2} \mathrm{O}_{3} \mathrm{~S}^{\bullet+}$, 427.2994; found: 427.2997.

\section{Compound $1 \mathrm{~b}$}


A solution of $\mathbf{3 b}$ (400 mg, $0.94 \mathrm{mmol})$ in anhydrous THF (30 mL) was deoxygenated with $\mathrm{N}_{2}$ for 1 h before a solution of $\mathrm{CsOH} \cdot \mathrm{H}_{2} \mathrm{O}(470 \mathrm{mg}, 2.80 \mathrm{mmol}, 3$ eq. $)$ in anhydrous $\mathrm{MeOH}(5 \mathrm{~mL})$, which was deoxygenated for $1 \mathrm{~h}$ with $\mathrm{N}_{2}$, was added dropwise via a syringe. The reaction mixture was stirred $4 \mathrm{~h} 30$, whereafter the solvent was evaporated in vacuo and the resulting orange residue was dissolved in $\mathrm{CH}_{2} \mathrm{Cl}_{2}(50 \mathrm{~mL})$, washed with $\mathrm{H}_{2} \mathrm{O}(3 \times 30 \mathrm{~mL})$ and dried $\left(\mathrm{MgSO}_{4}\right)$. Evaporation of the solvent gave an orange oil which was purified by column chromatography (silica gel, eluent $\left.\mathrm{CH}_{2} \mathrm{Cl}_{2} / \mathrm{MeOH} 98: 2\right)$ yielding $\mathbf{1 b}$ as an orange oil (180 mg, $\left.50 \%\right) ;{ }^{1} \mathrm{H} \mathrm{NMR}\left(500 \mathrm{MHz}, \mathrm{CDCl}_{3}\right): \delta$ 1.20-1.80 (m, 35H), 2.18 (bs, $\left.2 \mathrm{H}, \mathrm{CH}_{2} \mathrm{CO}\right), 2.70$ (t, $2 \mathrm{H}, \mathrm{CH}_{2} \mathrm{~S}, J=6 \mathrm{~Hz}$ ), 3.67 (bs, $\left.1 \mathrm{H}\right)$; ${ }^{13} \mathrm{C} \mathrm{NMR}$ $\left(125.75 \mathrm{MHz}, \mathrm{CDCl}_{3}\right): \delta 24.2,24.8,24,9,27.7,28.1,28.2,28.3,28.4,28.5,28.6,28.7,30.0,33.2$, 34.7, 38.4, 171.7, , one signal is missing or overlapping; FAB-MS: calcd for $\mathrm{C}_{21} \mathrm{H}_{41} \mathrm{~N}_{2} \mathrm{O}_{2} \mathrm{~S}^{\bullet+}$, 385.2889; found: 385.2899 .

\section{Compound 3c}

To a stirred solution of 16-(acetylthio)hexadecanoic acid $2 \mathrm{c}(230 \mathrm{mg}, 0.70 \mathrm{mmol})$ in $\mathrm{CH}_{2} \mathrm{Cl}_{2}(20$ $\mathrm{mL})$ at $0^{\circ} \mathrm{C}$ were added 4-aminoTEMPO (180 $\left.\mathrm{mg}, 1.05 \mathrm{mmol}\right)$ in $\mathrm{CH}_{2} \mathrm{Cl}_{2}$ (5 mL), 1hydroxybenzotriazole (HOBT) (140 mg, $1.05 \mathrm{mmol}$ ) and finally dicyclohexylcarbodiimide (220 $\mathrm{mg}, 1.05 \mathrm{mmol}$ ). The reaction mixture was allowed to attain room temperature and stirred under $\mathrm{N}_{2}$ for $24 \mathrm{~h}$. The precipitate of dicyclohexylurea was eliminated by filtration. The solvent was evaporated under reduced pressure and the resulting residue was purified by column chromatography (silica gel, eluent $\mathrm{CH}_{2} \mathrm{Cl}_{2} / \mathrm{MeOH}$ 96:4) giving 3c as an orange oil (280 mg, $83 \%$ ); ${ }^{1} \mathrm{H}$ NMR (500 MHz, $\left.\mathrm{CDCl}_{3}\right): \delta$ 1.20-1.50 (m, 32H), 1.55-1.85 (m, 8H), $1.97(\mathrm{~m}, 2 \mathrm{H}), 2,22(\mathrm{bs}, 2 \mathrm{H}$, $\mathrm{CH}_{2} \mathrm{CO}$ ), $2.38\left(\mathrm{~s}, \mathrm{CH}_{3} \mathrm{CO}\right), 2.92\left(\mathrm{t}, \mathrm{CH}_{2} \mathrm{~S}, J=7 \mathrm{~Hz}\right), 3.25$ (bs, $\left.1 \mathrm{H}\right) ;{ }^{13} \mathrm{C} \mathrm{NMR}(125.75 \mathrm{MHz}$, $\left.\mathrm{CDCl}_{3}\right): \delta 21.6,22.0,22.3,22.5,22.7,25.7,25.9,26.1,26.2,26.3,26.35,26.4,26.46,26.5,27.8$, 31.1, 31.8, 37.0, 52.6, 169.5, 193.0. FAB-MS: calcd for $\mathrm{C}_{27} \mathrm{H}_{51} \mathrm{~N}_{2} \mathrm{O}_{3} \mathrm{~S}^{\bullet+}$, 483.3620; found: 483.3636.

\section{Compound 1c}

A solution of 3c (163 mg, $0.34 \mathrm{mmol})$ in anhydrous THF (30 mL) was deoxygenated with $\mathrm{N}_{2}$ for 1 h before a solution of $\mathrm{CsOH} \bullet \mathrm{H}_{2} \mathrm{O}(170 \mathrm{mg}, 1.01 \mathrm{mmol}, 3$ eq. $)$ in anhydrous $\mathrm{MeOH}(5 \mathrm{~mL})$, which was deoxygenated for $1 \mathrm{~h}$ with $\mathrm{N}_{2}$, was added dropwise via a syringe. The reaction mixture was stirred $4 \mathrm{~h}$, whereafter the solvent was evaporated in vacuo and the resulting orange residue was 
dissolved in $\mathrm{CH}_{2} \mathrm{Cl}_{2}(50 \mathrm{~mL})$, washed with $\mathrm{H}_{2} \mathrm{O}(3 \times 30 \mathrm{~mL})$ and dried $\left(\mathrm{MgSO}_{4}\right)$. Evaporation of the solvent gave an orange oil which was purified by column chromatography (silica gel, eluent $\mathrm{CH}_{2} \mathrm{Cl}_{2} / \mathrm{MeOH} 90: 10$ ) yielding 1c as an orange oil (100 mg, $67 \%$ ); ${ }^{1} \mathrm{H}$ NMR (500 MHz, $\left.\mathrm{CDCl}_{3}\right): \delta$ 1.10-1.50 (m, 33H), 1.60-1.80 (m, 8H), 2.01 (bs, 2H), 2.24 (bs, 2H, $\left.\mathrm{CH}_{2} \mathrm{CO}\right), 2.74\left(\mathrm{t}, 2 \mathrm{H}, \mathrm{CH}_{2} \mathrm{~S}, J=\right.$ $6.5 \mathrm{~Hz}), 3.41(\mathrm{~s}, 1 \mathrm{H}) ;{ }^{13} \mathrm{C} \mathrm{NMR}\left(125.75 \mathrm{MHz}, \mathrm{CDCl}_{3}\right): \delta 23.2,23.7,23,9,26.6,27.2,27.3,27.35$, 27.5, 27.57, 27.6, 27.7, 27.8, 28.0, 29.0, 29.1, 32.2, 37.3, 38.2, 47.2, 52.3, 170.7; FAB-MS: calcd for $\mathrm{C}_{25} \mathrm{H}_{49} \mathrm{~N}_{2} \mathrm{O}_{2} \mathrm{~S}^{\bullet+}$, 441.3515; found: 441.3500 . 


\section{CHARACTERIZATION BY ELECTROCHEMISTRY}

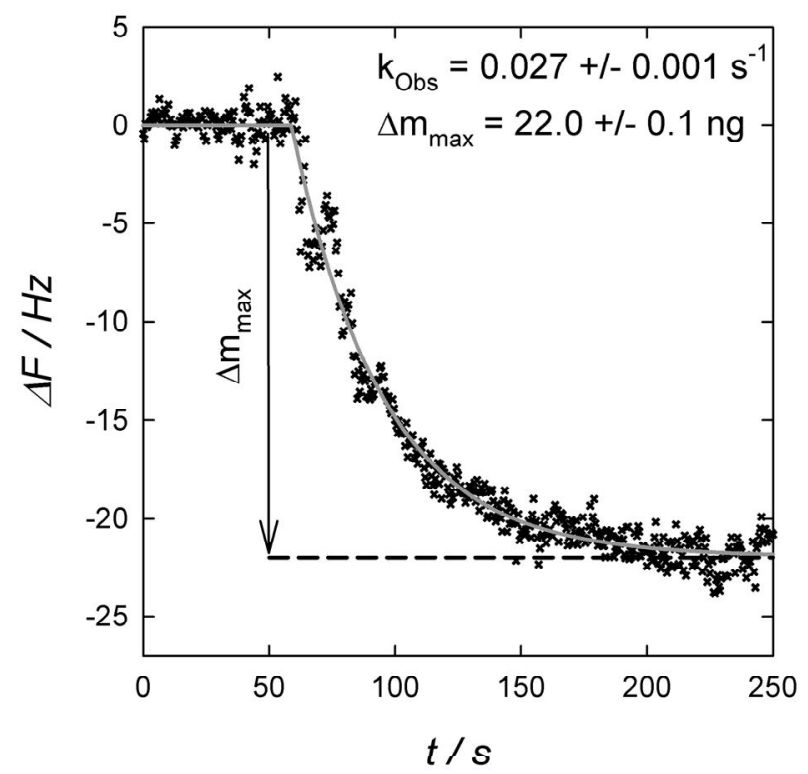

Figure SI-1. Frequency variations as a function of time of the gold coated quartz crystal during the addition of a $1 \mathrm{mM} \mathrm{CH} \mathrm{Cl}_{2}$ solution of $\mathbf{1 a}$ into the QCM cell. The data points have been fitted according to the Langmuir adsorption isotherm model. ${ }^{[\mathrm{S} 2]}$

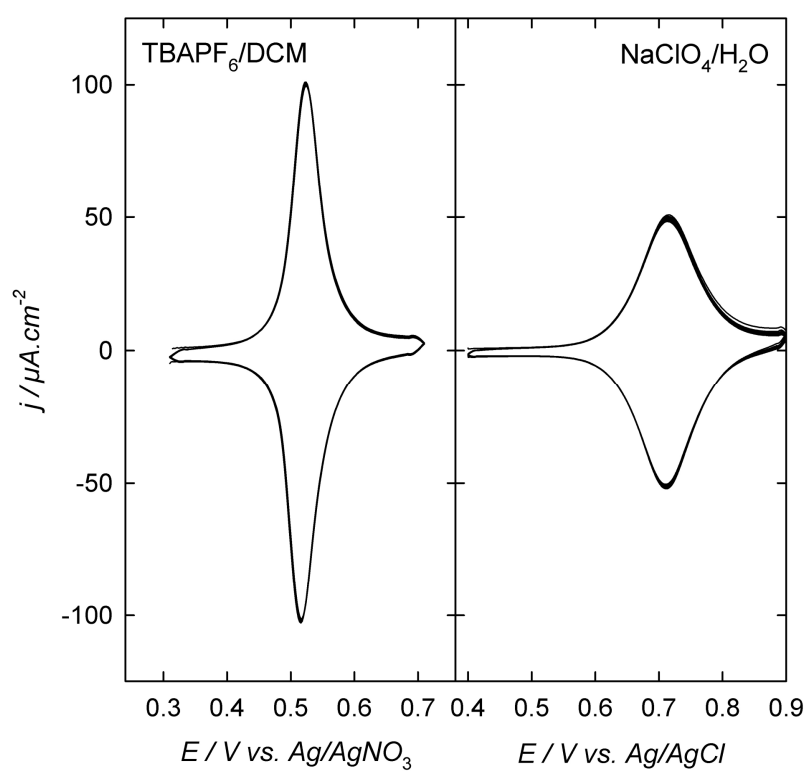

Figure SI-2: (left): CVs of SAM prepared from $1 \mathbf{b}$ in $0.1 \mathrm{M} \mathrm{Bu}_{4} \mathrm{NPF}_{6} / \mathrm{CH}_{2} \mathrm{Cl}_{2}$; (right): CVs of SAM prepared from $\mathbf{1 b}$ in $0.1 \mathrm{M} \mathrm{NaClO}_{4} / \mathrm{H}_{2} \mathrm{O}(\mathrm{pH}$ 7). Nitroxyl radical SAMs were stable: no decay of current was observed after 20 repetitive cycles at $0.1 \mathrm{~V} . \mathrm{s}^{-1}$. 


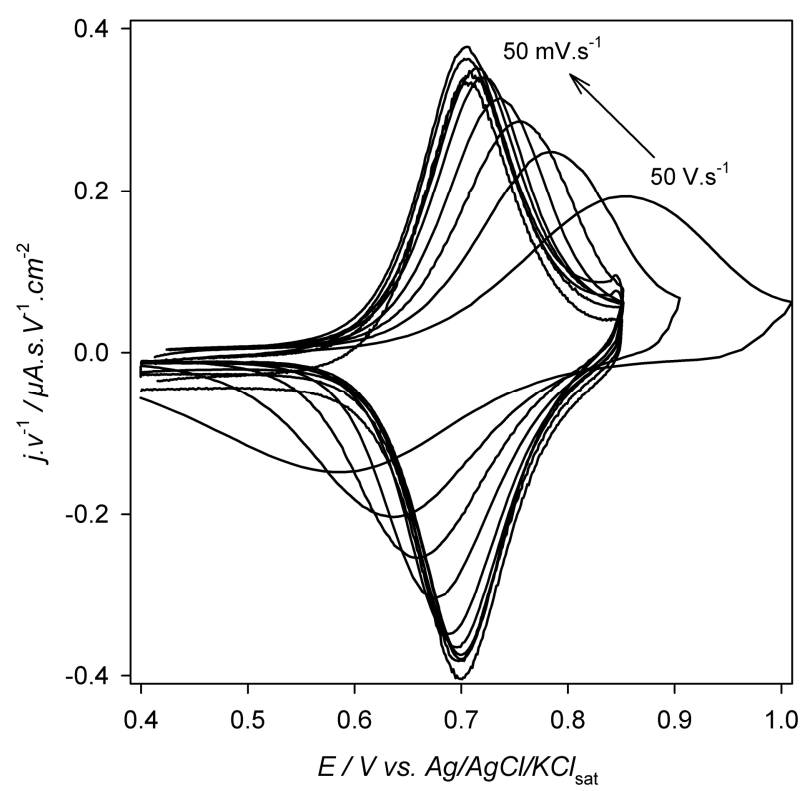

Figure SI-3: CVs of SAM prepared from 1c vs. scan rate in $\mathrm{HClO}_{4} / \mathrm{H}_{2} \mathrm{O}(\mathrm{pH}=2)$. The current has been normalized to scan rate $\left(0.05\right.$ to $\left.50 \mathrm{~V} \cdot \mathrm{s}^{-1}\right)$.

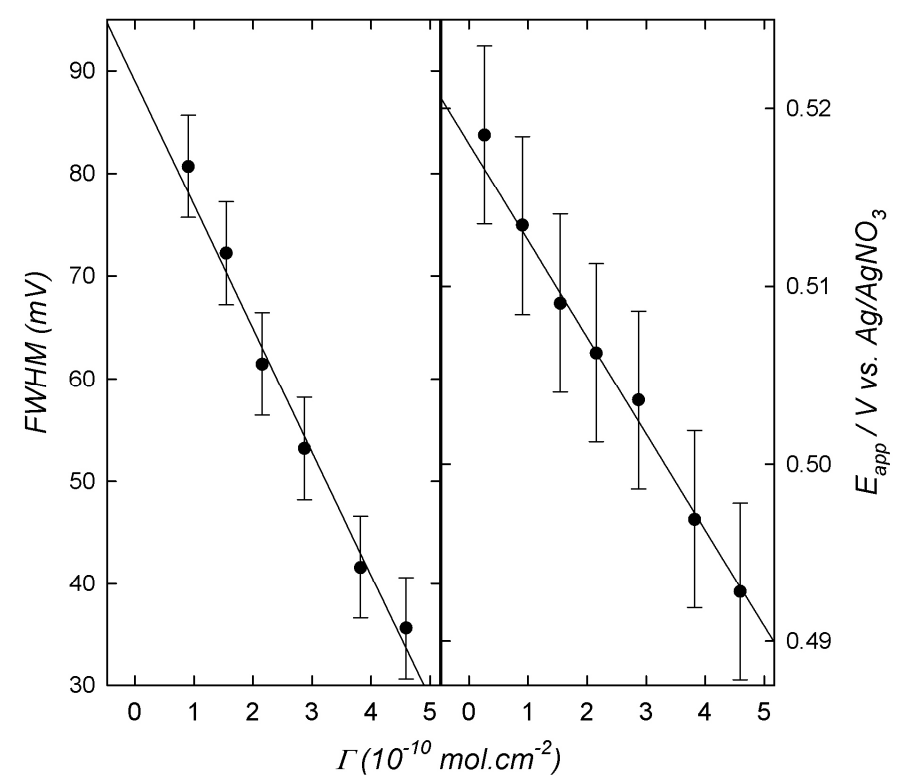

Figure SI-4: (left): Full width at half maximum (FWHM) as a function of the surface coverage; (right): Apparent redox potential $\left(\mathrm{E}_{\text {app }}\right)$ as a function of the surface coverage. Mixed SAMs were prepared from different 1c:decanethiol ratios, leading to $4.6,3.8,2.9,2.1,1.5$ and $0.910^{-10} \mathrm{~mol} . \mathrm{cm}^{-2}$. 


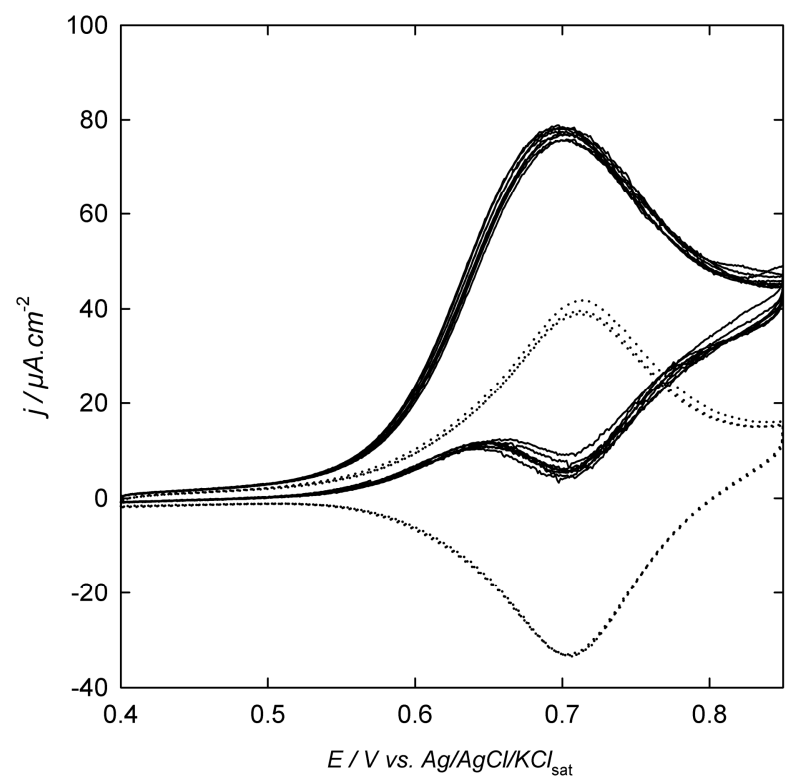

Figure SI-5: (Dashed line): CVs of SAMs prepared from 1c in absence of benzyl-alcohol; (Solid line): CVs of SAMs prepared from 1c in presence of $10 \mathrm{mM}$ benzyl-alcohol. All CVs were performed in $0.1 \mathrm{M} \mathrm{NaClO} / / \mathrm{NaOH} / \mathrm{H}_{2} \mathrm{O}$ $(\mathrm{pH}=10)$ at $0.1 \mathrm{~V} \cdot \mathrm{s}^{-1}$ under 20 repetitive cycles. 


\section{REFERENCES}

[S1] S. Svedhem, C.-A. Hollander, J. Shi, P. Konradsson, B. Liedberg, S. C. T. Svensson, J. Org. Chem. 2001, 66, 4494-4503

[S2] a) D. S. Karpovich, G. J. Blanchard, Langmuir, 1994, 10, 3315-3322; b) It is possible to extract the deposition rate constant $\left(k_{\mathrm{obs}}\right)$ from the following integrated equation:

$$
\theta(t)=K^{\prime}\left[1-\exp \left(-k_{\text {Obs }} t\right)\right] \text { where }\left\{\begin{array}{l}
k_{\text {Obs }}=k_{a} C+k_{d} \\
K^{\prime}=\frac{C}{C+\frac{k_{d}}{k_{a}}}
\end{array}\right.
$$

$\theta$ is the fraction of surface covered, $(1-\theta)$ represents the available sites for adsorption and $C$ is the analytical concentration. The values of both $k_{\mathrm{a}}$ and $k_{\mathrm{d}}$ corresponding to adsorption/desorption rate constants enable the kinetic parameters to be calculated. The values of $K^{\prime}$ and $k_{\mathrm{obs}}$ are obtained by fitting the experimental data to the equation. 